\title{
Secreted recombinant human IL-24 protein inhibits the proliferation of esophageal squamous cell carcinoma Eca-109 cells in vitro and in vivo
}

\author{
QUNFENG MA $^{1 *}$, BANGMING JIN $^{2,3 *}$, YAO ZHANG $^{2 *}$, YINAN SHI $^{2}, \mathrm{CHI}_{\text {ZHANG }}^{2}$, DAN LUO $^{2}$, \\ PENGKUN WANG $^{2}$, CUIMI DUAN ${ }^{4}$, HEYU SONG $^{2}$, XUE LI $^{2}$, XUEFENG DENG $^{1}$, \\ ZHINAN $\mathrm{CHEN}^{5}$, ZILING WANG ${ }^{2}$, HONG JIANG ${ }^{2}$ and YAN LIU ${ }^{3}$
}

\begin{abstract}
${ }^{1}$ Department of Thoracic Surgery, Affiliated Hospital of the Academy of Military Medical Sciences, Fengtai, Beijing 100071;
${ }^{2}$ College of Life Science and Bioengineering, School of Science, Beijing Jiaotong University, Haidian, Beijing 100044;

${ }^{3}$ College of Life Science, Southwest University, Beibei, Chongqing 400715; ${ }^{4}$ Department of Biological Diagnosis,

Beijing Institute of Basic Medical Sciences, Haidian, Beijing 100850; ${ }^{5}$ Cell Engineering Research Center,

The Fourth Military Medical University, Xicheng, Xi'an, Shaanxi 710032, P.R. China
\end{abstract}

Received November 17, 2015; Accepted December 16, 2015

DOI: $10.3892 / o r .2016 .4633$

\begin{abstract}
Interleukin-24 (IL-24) displays cancer-specific apoptosis-inducing properties in a broad spectrum of human tumors without harmful effects on normal cells. The human IL-24 protein is secreted as a glycosylated protein and functions as a pro-Th1 cytokine and a potent antiangiogenic molecule. However, the function of secreted recombinant human IL-24 (srhIL-24) protein in esophageal squamous cell carcinoma (ESCC) cells has not been studied. In the present study, we prepared a stable site-specific-integrated cell line, Flp-In ${ }^{\mathrm{TM}} \mathrm{CHO} / \mathrm{IL}-24$ (FCHO/IL-24), which secreted rhIL-24 at a higher level than three random-integrated cell lines. In vitro, we identified that the purified srhIL-24 inhibited proliferation and induced the apoptosis of ESCC Eca-109 cells and activated STAT3, which was related with the IL-20 receptors. In vivo, the tumorigenicity of Eca-109 cells was significantly inhibited by s.c. injection of FCHO/IL-24 cells. Decreased tumor microvessel density and an increased number of TUNEL-positive tumor cells were associated with tumor growth inhibition, indicating the presence of antiangiogenic activity and induction of apoptotic activity. In summary,
\end{abstract}

Correspondence to: Dr Hong Jiang, College of Life Science and Bioengineering, School of Science, Beijing Jiaotong University, 3 Shangyuancun, Haidian, Beijing 100044, P.R. China

E-mail: jhong@bjtu.edu.cn

Dr Yan Liu, College of Life Science, Southwest University, 2 Tianshenglu, Beibei, Chongqing 400715, P.R. China

E-mail: 1099380052@qq.com

${ }^{*}$ Contributed equally

Key words: esophageal squamous cell carcinoma, recombinant protein, IL-24, apoptosis, site-specific-integrated Flp- $\mathrm{In}^{\mathrm{TM}} \mathrm{CHO}$ cells the present study demonstrated that srhIL-24 induced growth inhibition and apoptosis in ESCC Eca-109 cells in vitro and in vivo, which may be mediated by the receptor pathway.

\section{Introduction}

Esophageal carcinoma is the eighth most common cancer worldwide, with 482,000 new cases in 2008, and is the sixth most common cause of cancer-related deaths with 406,000 deaths (1). China has one of the highest incidences of esophageal carcinoma in the world. The predominant type of esophageal carcinoma is esophageal squamous cell carcinoma (ESCC), and the crude mortality rate in 2004-2005 was $15.2 / 100,000$ (2). Despite advances in surgery and chemotherapy, the majority of patients have a poor prognosis since they are initially diagnosed in an advanced stage of disease, and frequently present with recurrence and are not responsive to further chemotherapy (3). The ESCC mortality and incidence rates are similar, and the 5-year overall survival rate is less than $15 \%$ (4). These facts emphasize the need to develop new effective therapies for ESCC.

One of the most encouraging candidates is melanoma differentiation-associated gene-7 (mda-7), also known as interleukin-24 (IL-24), which was identified by subtraction hybridization of cDNA libraries prepared from terminally differentiated human melanoma cells treated with human fibroblast interferon and mezerein (5). IL-24 is considered to be a tumor suppressor due to its ability to selectively kill and induce apoptosis in a wide range of cancer cells, both in vitro and in vivo, with minimal toxicity to normal cells (6). Of importance, IL-24 also exerts immunomodulatory effects (7), displays anti-angiogenic properties, and enhances tumor cell sensitivity to chemotherapy agents and radiotherapy (6). Dr P.D. Fisher, the discoverer of IL-24, suggested that it may be the long sought-after and proverbial 'magical bullet' for a diverse set of cancers (8). Although the biological activity of IL-24 was identified by adenovirus expressing IL-24 (Ad-IL-24), 
overexpression of recombinant human IL-24 (rhIL-24) protein in tumor cells is the most critical factor, and the recombinant protein has advantages over Ad with regard to tumor treatment, such as lower cytotoxicity, higher activity and specificity, and easier usage. The rhIL-24 protein is usually expressed in different expression systems, such as bacteria (9) and mammalian cells (7), but seldom in yeast (10) or insects (11). However, secreted recombinant human IL-24 (srhIL-24) purified from mammalian cell supernatant has the highest antitumor activity at the lowest concentration in diverse cancer cells, such as melanoma (12-14), pancreatic $(15)$, lung $(14,16)$, prostate (14), cervical (14) and breast cancer (17). srhIL-24 has many functions apart from its inhibitory activity in tumor cells, similar to Ad-IL-24. Caudell et al (7) demonstrated in human peripheral blood mononuclear cells that srhIL-24 plays a role as a pro-Th1 cytokine and induces secretion of IL-6, IFN- $\gamma$, TNF- $\alpha$, IL-1 $\beta$, IL-12 and GM-CSF, which may evoke an antitumor immune response. srhIL-24 has potent anti-angiogenic activity in vitro and in vivo (16). In addition, srhIL-24 protein modulates the sensitivity of melanoma cells to the EGFR inhibitor erlotinib (18) and temozolomide (13) similar to Ad-IL-24, suggesting that a combination treatment of rhIL-24-mediated molecular therapy may be a novel treatment strategy for human melanoma. Secreted rhIL-24 by normal cells inhibits invasion and sensitizes specific cancer cells containing functional IL-20R to radiation (19).

With regard to ESCC, Ma et al (20) reported that Ad-IL-24 enhanced agent-mediated cytotoxicity in certain cell lines (TE-1, TE-2, TE-10, TE-11, YES-2, YES-4, YES-5, YES-6 and T.Tn cells), and the combination with 5-fluorouracil, cisplatin, mitomycin and etoposide produced greater antitumor effects than monotherapy. Our previous study showed that the human IL-24 peptide created by computer-guided design contributed to suppression of proliferation in ESCC Eca-109 cells (21). It is not clear whether rhIL-24 protein could inhibit ESCC cells and how it functions. In the present study, we prepared a stable site-specific integrated cell line, Flp-In ${ }^{\mathrm{TM}} \mathrm{CHO} / \mathrm{IL}-24$ (FCHO/IL-24), with high expression levels of secreted rhIL-24 and tested the antitumor activity of srhIL-24. We identified that srhIL-24 had high potent antitumor activity in ESCC Eca-109 cells in vitro and in vivo and activated STAT3, which may be mediated by the receptor pathway. The data strongly suggest that srhIL-24 may represent a potential treatment for ESCC.

\section{Materials and methods}

Reagents. Anti-IL-24 (AF1965 and MAB1965) and IL-20R antibodies (MAB11762, AF1788 and MAB2770) were purchased from R\&D Systems, China (Shanghai, China). The pSTAT3 (Tyr705) rabbit antibody (D3A7) and antiSTAT3 $\alpha$ rabbit antibody (D1A5) were purchased from Cell Signaling Technology (Beverly, MA, USA). The anti-PCNA (ZM-0213), Ki-67 (ZA-0502) and secondary antibodies were purchased from Zhongshan Golden Bridge Biotechnology (Beijing, China). The anti-CD34 antibody (BA0532) was purchased from Boster Biological Technology Ltd. (Wuhan, China). The anti-His ${ }_{6}$ antibody was a product of Beijing B\&M Biotechnology (Beijing, China). The IL-24 ELISA kit (F01531) was purchased from Xitang Biotechnology (Shanghai, China).
The Flp-In system plasmids (pCDNA5/FRT and pOG44) and pCEP4-IL-24 containing IL-24 full cDNA were kindly gifted by Dr Zhiwei Sun of the Beijing Institute of Biotechnology and Dr Jean-Christophe Renauld from Luding Institute for Cancer Research in Belgium, respectively.

Cell culture. Flp- $\mathrm{In}^{\mathrm{TM}} \mathrm{CHO}$ (FCHO) cells obtained from Invitrogen (Carlsbad, CA, USA) were maintained in F12 nutrient mixture medium supplemented with $10 \%$ fetal bovine serum (FBS), $100 \mu \mathrm{g} / \mathrm{ml}$ penicillin/streptomycin and $100 \mu \mathrm{g} / \mathrm{ml}$ Zeocin. Human melanoma A375 cells and lung cancer A549 cells were purchased from the Institute of Basic Medical Sciences, Chinese Academy of Medical Sciences. ESCC Eca-109 cells, the human embryo lung fibroblast cell line HEL and human embryonic kidney 293 cells (HEK293) were kindly provided by Dr XiaoFei Zheng of the Beijing Institute of Radiation Medicine. A375, A549, Eca-109, HEL and HEK293 cells were checked by short tandem repeat (STR) analysis at the Beijing Microread Gene Technology (Beijing, China) and maintained in Dulbecco's modified Eagle's medium (DMEM) supplemented with $10 \% \mathrm{FBS}, 100 \mu \mathrm{g} / \mathrm{ml}$ penicillin/ streptomycin, 2 mmol/1 L-glutamine and HEPES buffer.

Production of secreted rhIL-24 protein. The fulllength cDNA of IL-24 with an additional $\mathrm{His}_{6}$-tag at the $\mathrm{COOH}$-terminus was cloned into the $\operatorname{pDNA}^{\mathrm{TM}} 5 /$ FRT. The recombinant plasmid pcDNA5/FRT-IL-24 was co-transfected with pOG44 into FCHO cells using the Lipofectamine 2000 method. The stable cells, FCHO/IL-24, were selected with $500 \mu \mathrm{g} / \mathrm{ml}$ hygromycin and identified by western blotting. Three other random-integrated cell lines (HEK293/pSecTag2A-IL-24, HEK293/pcDNA3.1myc/His-IL24 and HEK293/pCEP4-IL-24) were created by transfecting the plasmids containing the full-length cDNA of IL-24 (pSecTag2A-IL-24, pcDNA3.1myc/His-IL-24 and pCEP4-IL-24) into HEK293 cells, respectively. The stable cell lines were isolated by hygromycin $(400 \mu \mathrm{g} / \mathrm{ml})$ or $\mathrm{G} 418(600 \mu \mathrm{g} / \mathrm{ml})$. To identify and compare the expression level of srhIL-24, four types of engineered cells were seeded in 100-mm plates $\left(1.5 \times 10^{6}\right)$ in $10 \mathrm{ml}$ DMEM, respectively. The supernatant was collected at 1-4 days and assayed via ELISA. To purify the srhIL-24 protein on a large scale, FCHO/IL-24 cells were grown to $90 \%$ confluency in $150-\mathrm{mm}$ tissue culture plates for $72 \mathrm{~h}$. The supernatant was collected, centrifuged to remove cell debris, supplemented with protease inhibitors $[1 \mu \mathrm{g} / \mathrm{ml}$ leupeptin, $1 \mu \mathrm{g} / \mathrm{ml}$ pepstatin and $0.5 \mathrm{mmol} / 1$ phenylmethylsulphonyl fluoride (PMSF)], mixed with Ni-NTA slurry and incubated at $4^{\circ} \mathrm{C}$ overnight. The Ni-NTA slurry-containing supernatant was allowed to pass through a column to collect the beads. The beads were washed with binding buffer $(20 \mathrm{mmol} / \mathrm{l}$ sodium phosphate, $0.5 \mathrm{~mol} / 1 \mathrm{NaCl}, 20 \mathrm{mmol} / 1$ imidazole, $\mathrm{pH}$ 7.4), and rhIL-24 was eluted by elution buffer ( $250 \mathrm{mmol} / \mathrm{l}$ imidazole in binding buffer). The eluted fractions identified as containing secreted rhIL-24 by western blotting were pooled, desalted and concentrated. The final protein concentration was determined by ELISA. The size of rhIL-24 was determined by western blotting.

Western blotting. Cells lysates were treated with RIPA lysis buffer and the protein concentrations were determined 
with the Pierce BCA protein assay kit (Thermo Scientific, Waltham, MA, USA). Total protein (20-50 $\mu \mathrm{g}$ ) or $50 \mu 1$ supernatant was separated by $15 \%$ SDS-PAGE and transferred to a nitrocellulose membrane. After incubation in 5\% non-fat milk solution, the membranes were incubated in the anti-IL-24 antibody $(1: 400 ; \mathrm{AF} 1965)$ or anti-His ${ }_{6}$-tag antibody $(1: 1,000)$ at $4{ }^{\circ} \mathrm{C}$ overnight. The activation of STAT3 in tumor cells was detected using the anti-pSTAT3 antibody $(1: 1,000)$ and anti-STAT3 $\alpha(1: 1,000)$ antibody. The proteins were visualized on Kodak X-ray film (Rochester, NY, USA) by application of the enhanced chemiluminescence western blotting detection system (Thermo Scientific).

ELISA. The ELISA reaction to detect rhIL-24 was conducted in 96-well plates according to the manufacturer's instructions. Briefly, samples $(100 \mu \mathrm{l})$ were diluted, added to 96-well plates and incubated at $37^{\circ} \mathrm{C}$ for $2 \mathrm{~h}$. The plate was reacted with a biotinylated antibody against IL-24 for $1 \mathrm{~h}$ at $37^{\circ} \mathrm{C}$ and then HRP-streptavidin for $30 \mathrm{~min}$ at room temperature. The reaction was developed with the addition of TMB peroxidase substrate and stopped with $1 \mathrm{NH}_{2} \mathrm{SO}_{4}$. The optical density (OD) values were read on a Bio-Rad microplate reader Model 550 (Hercules, CA, USA) at $450 \mathrm{~nm}$. The concentration of IL-24 was determined via comparison with a standard curve.

Cell viability assay. Cell viability was assessed by MTT assay. Cells were seeded in 96-well plates (2,500 cells/well) for $24 \mathrm{~h}$ at $37^{\circ} \mathrm{C}$ and treated with purified rhIL-24 at different final concentrations $(0,1,5,10,20$ and $50 \mathrm{ng} / \mathrm{ml})$. On day 4 after treatment, the medium was removed and MTT was added to each well. The cells were maintained at $37^{\circ} \mathrm{C}$ for $4 \mathrm{~h}$; then $150 \mu 1$ of dimethyl sulfoxide (DMSO) was added to each well and mixed thoroughly. The absorbance was read on a Bio-Rad microplate reader Model 550 at $490 \mathrm{~nm}$. MTT absorbance of the untreated control cells was set to 1 to calculate the relative number of viable cells. The experiments were repeated at least three times to ensure reproducibility and statistical significance.

Clone formation assay. Cells (Eca-109, A375, A549 and HEL) were seeded at 400 cells $/ 10-\mathrm{cm}$ dish in triplicate and treated with purified rhIL-24 at final different concentrations $(0,1,5$, $10,20$ and $50 \mathrm{ng} / \mathrm{ml}) 24 \mathrm{~h}$ later. After 2 weeks of incubation, the clones were fixed with $4 \%$ formaldehyde, stained with Giemsa and colonies of $>50$ cells were enumerated.

Apoptosis assay. Cell apoptosis was detected via the Annexin V binding assay and FACS analysis. Cells (Eca-109, A375, A549 and HEL) were seeded at $4.5 \times 10^{4}$ cells/well in 6 -well plates and treated with purified rhIL-24 at different final concentrations $(0,1,10$ and $40 \mathrm{ng} / \mathrm{ml})$ on the following day. On day 4 after treatment, the cells were stained with FITC-labeled Annexin V and PI according to the manufacturer's instructions (KGA105-50; Annexin V-FITC apoptosis detection kit; Nanjing KeyGen Biotech, Nanjing, China) and FACS assay was performed immediately after staining. For the xenograft tumor tissue, the apoptosis of a section was analyzed by TUNEL staining using the DeadEnd ${ }^{\mathrm{TM}}$ Colorimetric TUNEL system (G7130; Promega Corporation, Beijing, China) following the manufacturer's protocol.
Hematoxylin was applied as a counter stain. In each sample, the number of apoptotic tumor cells from 50 different fields was evaluated at high magnification $(\mathrm{x} 400)$.

Evaluation of tumor growth in vivo. The effect of rhIL-24 in Eca-109 cells in vivo was investigated by xenograft tumors in nude mice as previously described (16). All applicable international, national and/or institutional guidelines for the care and use of animals were followed. All procedures performed in studies involving animals were in accordance with ethical standards of the Center of Biomedical Analysis of Tsinghua University where the studies were conducted. First, the cell number of Eca-109-induced tumors in athymic BALB/c female nude mice was identified by injecting s.c. $1 \times 10^{6}, 2 \times 10^{6}$ or $5 \times 10^{6}$ cells into the lower right flank of mice, respectively. Each group consisted of three animals, and tumor growth was monitored for 30 days. Tumor length and width were measured using a Vernier caliper every other day without knowledge of the treatment groups, and the tumor volume was calculated by 'length $\mathrm{x}$ width ${ }^{2} / 2$ '. At the same time, FCHO and FCHO/IL-24 cells were tested for their ability to induce tumors. Aliquots of cells $\left(1 \times 10^{6}\right.$ and $\left.2 \times 10^{6}\right)$ were injected s.c., as described above. Then, Eca-109 $\left(5 \times 10^{7} / \mathrm{ml}\right)$, FCHO $\left(2 \times 10^{7} / \mathrm{ml}\right)$ and FCHO/IL-24 cells $\left(2 \times 10^{7} / \mathrm{ml}\right)$ were resuspended in sterile phosphate-buffered saline (PBS) at different cell concentrations, respectively. There were 8 animals in the experimental group and each animal received $7 \times 10^{6}$ cells $(200 \mu \mathrm{l})$ into the lower right flank, which consisted of $5 \times 10^{6}$ Eca-109 cells and $2 \times 10^{6} \mathrm{FCHO} / \mathrm{IL}-24$ cells. Each animal in the control group received a mixture of Eca-109 and FCHO cells, as described above. After 30 days, the animals were euthanized, and the tumors were analyzed by immunohistochemical staining with H\&E, PCNA or Ki-67, CD34, IL-24 and TUNEL staining. Finally, Eca-109 cells were injected s.c. into the lower right flanks of nude mice. When the size of the tumors reached $50-100 \mathrm{~mm}^{3}$ (nearly 7 days), the animals were divided randomly into two groups. The animals in the experimental group were injected s.c. into the upper right flank with $200 \mu \mathrm{l}$ Matrigel containing FCHO/IL-24 cells ( $\left.2 \times 10^{6} / \mathrm{animal}\right)$, and the mice in the control group were injected with Matrigel containing FCHO cells. The tumor volume was monitored and the tumor sections were analyzed as described above.

Immunohistochemical analysis. Immunohistochemical labeling was performed on $10 \%$ formalin-fixed, paraffinembedded tumor tissues (cut into $4-\mu \mathrm{m}$ secions). After being deparaffinized in xylene and rehydrated in graded concentrations of ethanol, the sections were recovered in citrate buffer and blocked with $3 \% \mathrm{H}_{2} \mathrm{O}_{2}$ and $10 \%$ serum. The primary antibodies were added and incubated overnight at $4^{\circ} \mathrm{C}$ at various dilutions as follows: IL-24 (1:20; AF1965), PCNA (1:500; ZM-0213), Ki-67 (1:100; ZA-0502) and CD34 (1:100; BA-0532). Then, the slides were incubated with a secondary antibody and the horseradish peroxidase-streptavidin complex reagent for $30 \mathrm{~min}$, respectively (Beijing Golden Bridge Biotechnology, Beijing, China). The immunolabeling was developed with the chromogen 3,3'-diaminobenzidine tetrahydrochloride (DAB). Hematoxylin was applied as a counter stain. Tissue sections stained without the primary antibody served as the negative controls. The staining of tissue sections 
was analyzed and quantified, and the results were interpreted in a blinded manner.

Statistical analysis. All experiments were performed at least three times. Statistical comparisons between groups were performed using an unpaired Student's t-test with the Statistical Package for the Social Sciences (SPSS) software version 15 (SPSS, Inc., Chicago, IL, USA). $\mathrm{p}<0.05$ or $\mathrm{p}<0.01$ was considered to indicate a statistically significant result.

\section{Results}

Purification of rhIL-24 from the site-specific-integrated cell line FCHO/IL-24 with a high expression level of rhIL-24. Although the protein expressed in mammalian cells has a high biological function at a $\mathrm{ng} / \mathrm{ml}$ concentration, the expression level is lower than that in E. coli (22). To identify whether IL-24 cDNA site-specifically integrated at a specific genomic location is an advantage over random integration, we established a stable site-specific cell line, FCHO/IL-24, that secretes rhIL-24 using the Flp-In system (for generating stable mammalian expression cell lines by Flp recombinase-mediated integration; Invitrogen, Carlsbad, CA, USA). After culturing for $72 \mathrm{~h}$, the supernatant and lysates of FCHO/IL-24, FCHO/mock and FCHO cells were collected and examined by western blotting using anti-human IL-24 (AF1965) and anti-His ${ }_{6}$ antibodies. As shown in Fig. 1A, both the anti-IL-24 and the anti-His ${ }_{6}$ antibodies recognized the recombinant glycosylated protein in the supernatant (MW, $40 \mathrm{kDa}$ ) and the doublet intracellular protein in the lysates (MW, 23 and $30 \mathrm{kDa}$ ) of FCHO/IL-24 cells, as in previous studies $(23,24)$. The samples of $\mathrm{FCHO} /$ mock and FCHO did not display any detectable rhIL-24 expression. Thus, we successfully established the FCHO/IL-24 cell line to constitutively express secreted rhIL-24 protein.

At the same time, we established 3 random-integrated cell lines, HEK293/pSecTag2A-IL-24, HEK293/pcDNA3.1myc/ His-IL-24 and HEK293/pCEP4-IL-24, which could stably secrete rhIL-24 into the supernatant, as determined by western blotting assays (data not shown). To compare the expression level of srhIL-24 via ELISA, we collected the supernatant from the four cell types at different times (1-4 days). As shown in Fig. 1B, compared with the three random-integrated cell lines, FCHO/IL-24 secreted srhIL-24 protein at the highest level with a marked difference $(\mathrm{p}<0.05$ or $\mathrm{p}<0.01)$. The expression level of FCHO/IL-24 was 1.7, 5.7, 7.4 and $8.0 \mathrm{ng} / \mathrm{ml}$ at the respective times, which was more than that of HEK293/ pCEP4-IL-24 at 1.4, 4.0, 6.1 and $7.1 \mathrm{ng} / \mathrm{ml}$, respectively. The difference between the two cell lines was particularly notable $(\mathrm{p}<0.05)$ on day 2 . This experiment was repeated at least three times. Thus, the expression level of the site-specific stable cell line FCHO/IL-24 was higher than the levels in the three random-integrated cell lines. The rhIL-24 protein in the supernatant of FCHO/IL-24 cells was eluted by $250 \mathrm{mmol} / 1$ imidazole using $\mathrm{Ni}^{2+}$ affinity chromatography and recognized by the anti-IL-24 antibody (data not shown). The final concentration of purified srhIL-24 was $500 \mathrm{ng} / \mathrm{ml}$ after treatment of ultrafiltration, as determined by ELISA.

Secreted rhIL-24 inhibits ESCC Eca-109 cell growth and induces apoptosis in a dose-dependent manner. We showed
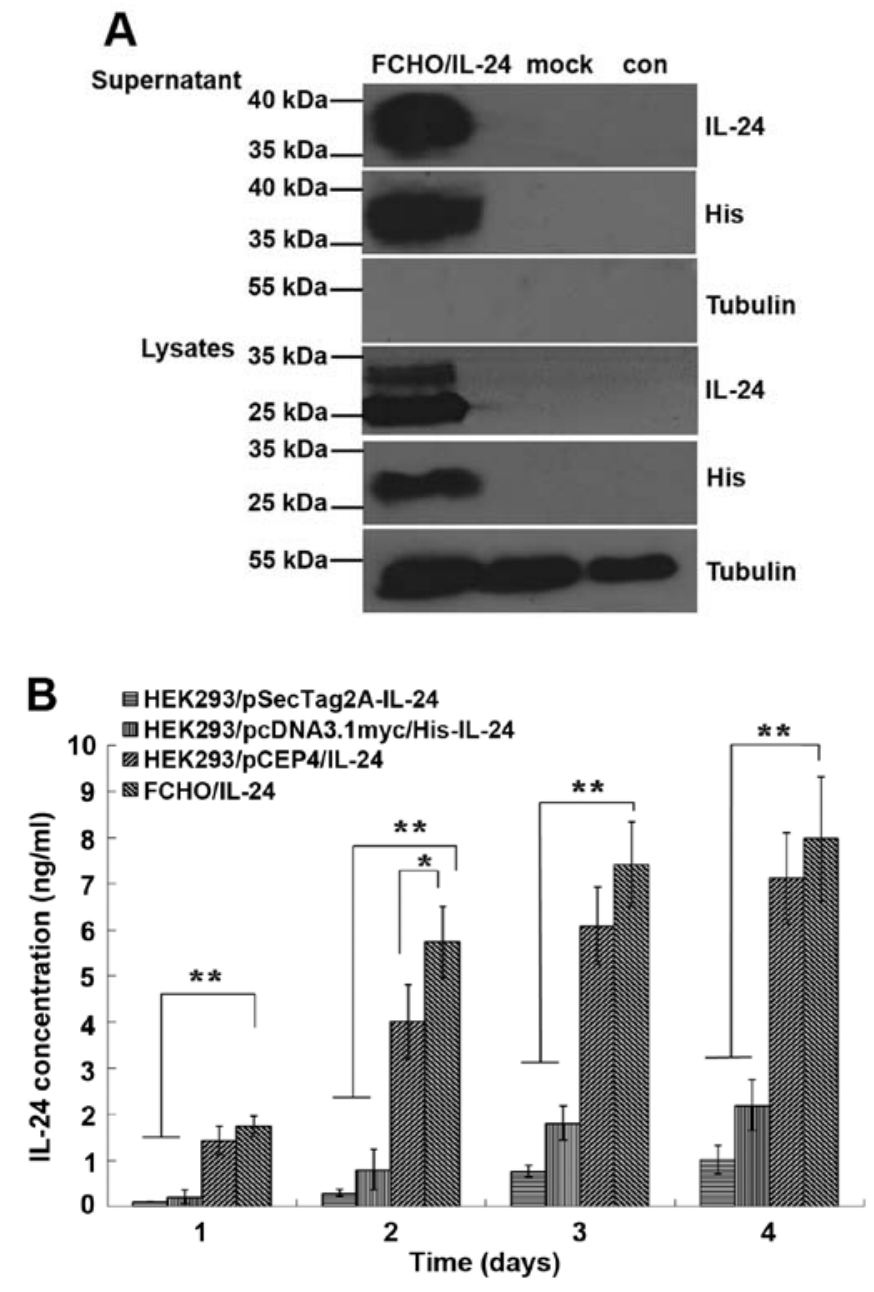

Figure 1. Purification of rhIL-24 from the site-specific integrated cell line FCHO/IL-24 with high expression level. (A) Both the supernatant and cell lysates from the FCHO/IL-24 cells were recognized by anti-IL-24 (AF1965) and anti-His ${ }_{6}$ antibodies by western blotting. The the Flp-In-CHO/mock (FCHO/mock) cells co-transfected with pOG44 and pcDNA5/FRT were used as a mock control (mock) and the Flp-In-CHO (FCHO) cells were the negative control (con). Tubulin was used as a sample control. (B) The expression level of srhIL-24 in the supernatant from the site-specific integrated cell line FCHO/IL-24 was higher than that of the three random-integrated cell lines (HEK293/pSecTag2A-IL-24, HEK293/pcDNA3.1myc/His-IL-24 and HEK293/pCEP4-IL-24) by ELISA at different times (1-4 days); $\left({ }^{* *} \mathrm{p}<0.01\right.$ and $\left.{ }^{*} \mathrm{p}<0.05\right)$.

that Eca-109, A375 and HEL cells were IL-20R-positive by immunofluorescence, while the A549 cell line showed positive staining for IL-20R2, and the two other receptor subunits were not expressed (21). Therefore, A375 cells were used as a positive control for the expression of IL-20 receptor complexes, which are the target receptors of IL-24; A549 cells were used as a negative control for receptor expression. The control for primary normal cells was HEL, which showed positive expression of IL-20R. The effects of rhIL-24 on cell growth were analyzed on day 4 using the MTT assay. Purified rhIL-24 was added at different concentrations $(0,1,5,10,20$ and $50 \mathrm{ng} / \mathrm{ml})$ to the cell culture media, and PBS was used as the untreated control. As shown in Fig. 2A, compared with the PBS-treated cells, rhIL-24 induced a significant decrease in the cell viability of the Eca-109 and A375 cells. In these two cell lines, a decrease in cell viability was evident even after treatment with $1 \mathrm{ng} / \mathrm{ml}$ 

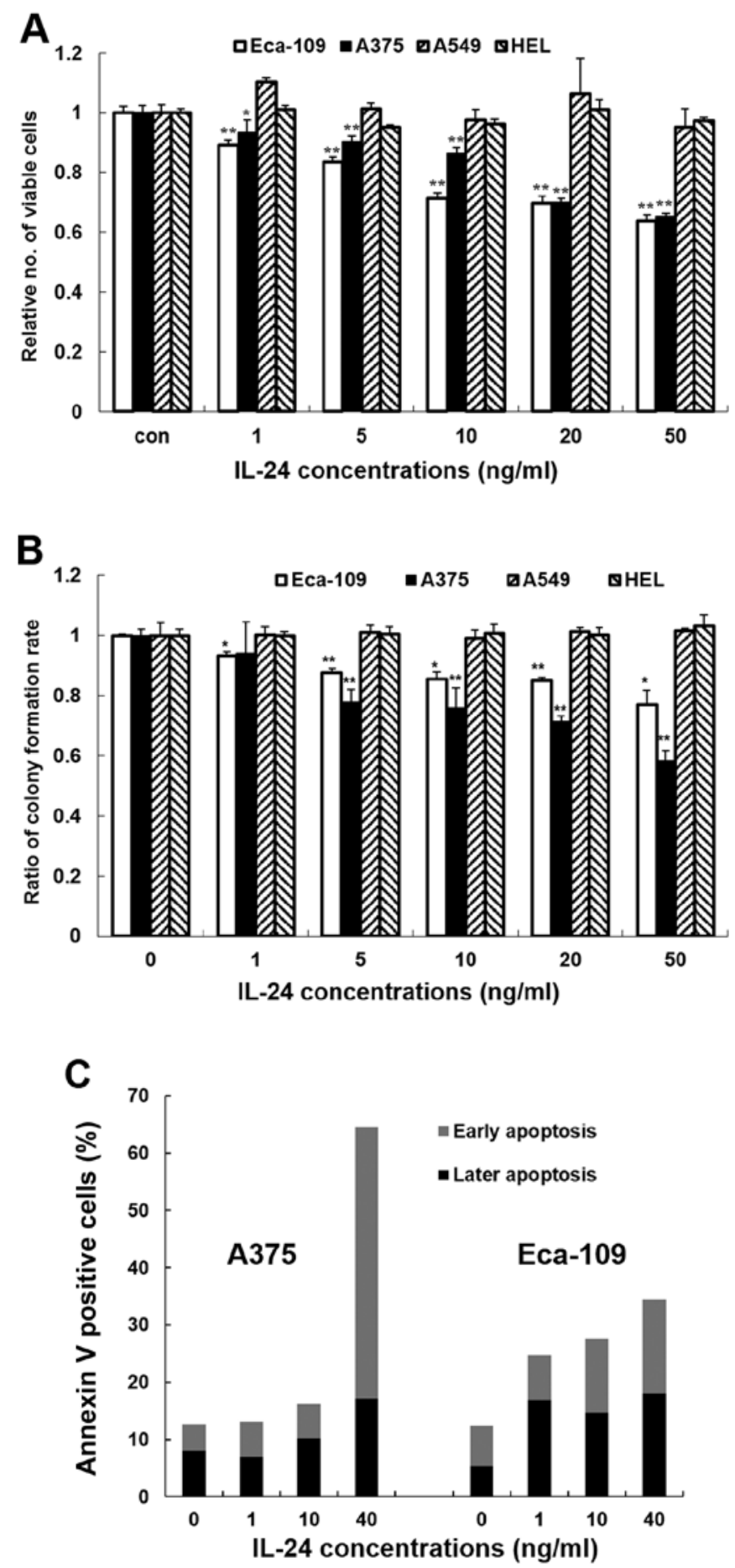

Figure 2. Secreted rhIL-24 inhibits ESCC Eca-109 cell growth and induces apoptosis in a dose-dependent manner. (A) Cells (Eca-109, A375, A549 or HEL) were treated with purified rhIL-24 $(1,5,10,20$ and $50 \mathrm{ng} / \mathrm{ml})$ for 4 days, and cell viability was evaluated by MTT assay. The numbers represent the ratio of the specific treatments indicated vs. control cells; columns, average of three independent experiments $(n=3) ;{ }^{* *} \mathrm{p}<0.01$ or $\mathrm{p}<0.05$ represents a significant difference compared with the control group. (B) The effect of srhIL-24 protein on colony formation in cancer and normal cells. A375, Eca-109, A549 or HEL cells were treated with srhIL-24 protein (0, $1,5,10,20$ and $50 \mathrm{ng} / \mathrm{ml}$ ) for 2 weeks, and the colony formation rate was evaluated as the ratio of clone number to cell number. Columns, the mean of three independent experiments $(n>3)$, and ${ }^{* *} \mathrm{p}<0.01$ represents a significant reduction compared with the untreated group. (C) srhIL-24 protein induces apoptosis in the A375 and Eca-109 cells. The indicated cells were seeded in 6 -well plates at a density of $4.5 \times 10^{5} /$ well and the next day they were treated with different concentrations of rhIL-24 (0, 1, 10 and $40 \mathrm{ng} / \mathrm{ml})$. Four days after treatment, the cells were harvested for Annexin V FITC/PI staining and FASC analysis. The data are shown as one of three independent experiments. $(\mathrm{p}<0.05)$, and increasing concentrations of rhIL-24 produced a more significantly pronounced effect $(\mathrm{p}<0.01)$. The highest percentage of inhibition of rhIL-24 in the Eca-109 and A375 cells was 34.69 and $36.21 \%$ at $50 \mathrm{ng} / \mathrm{ml}$, respectively. However, treatment with rhIL-24 at the same concentrations $(1-50 \mathrm{ng} / \mathrm{ml})$ did not decrease the viability of the other two cell lines (A549 and HEL). These results showed that the observed inhibitory activity in the MTT assays was attributable to rhIL-24. This effect was corroborated by a clone formation assay (Fig. 2B). These data demonstrated that rhIL-24 inhibited the growth and clone formation of the Eca-109 and A375 cells in a dosedependent manner and had no effect on A549 and HEL cells.

Previous studies have extensively demonstrated that secreted rhIL-24 can trigger apoptosis in a broad spectrum of tumors $(13,15,16)$. Annexin V binding and FACS assays were performed to determine whether secreted rhIL-24 induced apoptosis in the Eca-109 and A375 cells. As shown in Fig. 2C, both cancer cell lines underwent significant apoptosis after secreted rhIL-24 treatment in a dose-dependent manner. The apoptosis rates of Eca-109 and A375 cells were 34.5 and $64.5 \%$ when rhIL-24 was added at a final concentration of $40 \mathrm{ng} / \mathrm{ml}$, respectively. The results indicated that the secreted rhIL-24 protein robustly induced apoptosis in the ESCC Eca-109 and melanoma A375 cells in a dose-dependent manner compared with PBS treatment.

rhIL-24 protein-mediated killing of Eca-109 cells and activation of STAT3 may be related to IL-20 receptors. To confirm that the inhibitory effect was due to treatment with rhIL-24, cell viability was assessed using MTT assay 4 days after treatment with rhIL-24 $(20 \mathrm{ng} / \mathrm{ml})$ plus various neutralizing antibodies against IL-24 (AF1965 or MAB1965) or IL-20R (IL-20R1, IL-20R2 or IL-22R1) at a concentration of $200 \mathrm{ng} / \mathrm{ml}$. As shown in Fig. 3A, the anti-IL-24 antibody (AF1965 or MAB1965) significantly inhibited ( $<<0.05$ or $\mathrm{p}<0.01)$ IL-24-mediated cell killing in the Eca-109 cells, as did the anti-IL-20R antibodies (IL-20R1, IL-20R2 or IL-22R1) $(\mathrm{p}<0.01)$. The anti-IL-24 or anti-IL-20R antibodies also significantly reduced the killing of A375 cells $(\mathrm{p}<0.05$ or $\mathrm{p}<0.01$ ) (Fig. 3A). Treatment with immunoglobulin (Ig), a nonspecific control, had no effect on the cell killing by rhIL24. This result suggested that rhIL-24-mediated cell death was caused by extracellular mechanisms. At the same time, an anti-IL-24 or an anti-IL-20R antibody was not able to fully abrogate cell killing. These results suggest the possibility that other unappreciated functional receptor molecules and signaling pathways may allow them to antagonize the growth suppression of secreted rhIL-24 protein on cancer cells.

Recent studies have demonstrated the activation of STAT3 in tumor cells upon receptor engagement by srhIL-24 $(12,23)$. As shown in Fig. 3B, western blotting analysis showed that the addition of srhIL-24 (final concentration of $20 \mathrm{ng} / \mathrm{ml}$ ) in the culture media of Eca-109 cells increased the expression levels of the pSTAT- 3 protein at $4 \mathrm{~h}$, but not at $1 \mathrm{~h}$, as in A375 cells. On the basis of these studies, we identified that activity of srhIL-24 on the proliferation of Eca-109 and A375 cells and activation of STAT3, may be mediated by the receptor pathway.

rhIL-24 inhibits the tumorigenicity of Eca-109 cells in nude mice. We firstly identified the cell number of Eca-109 cells 


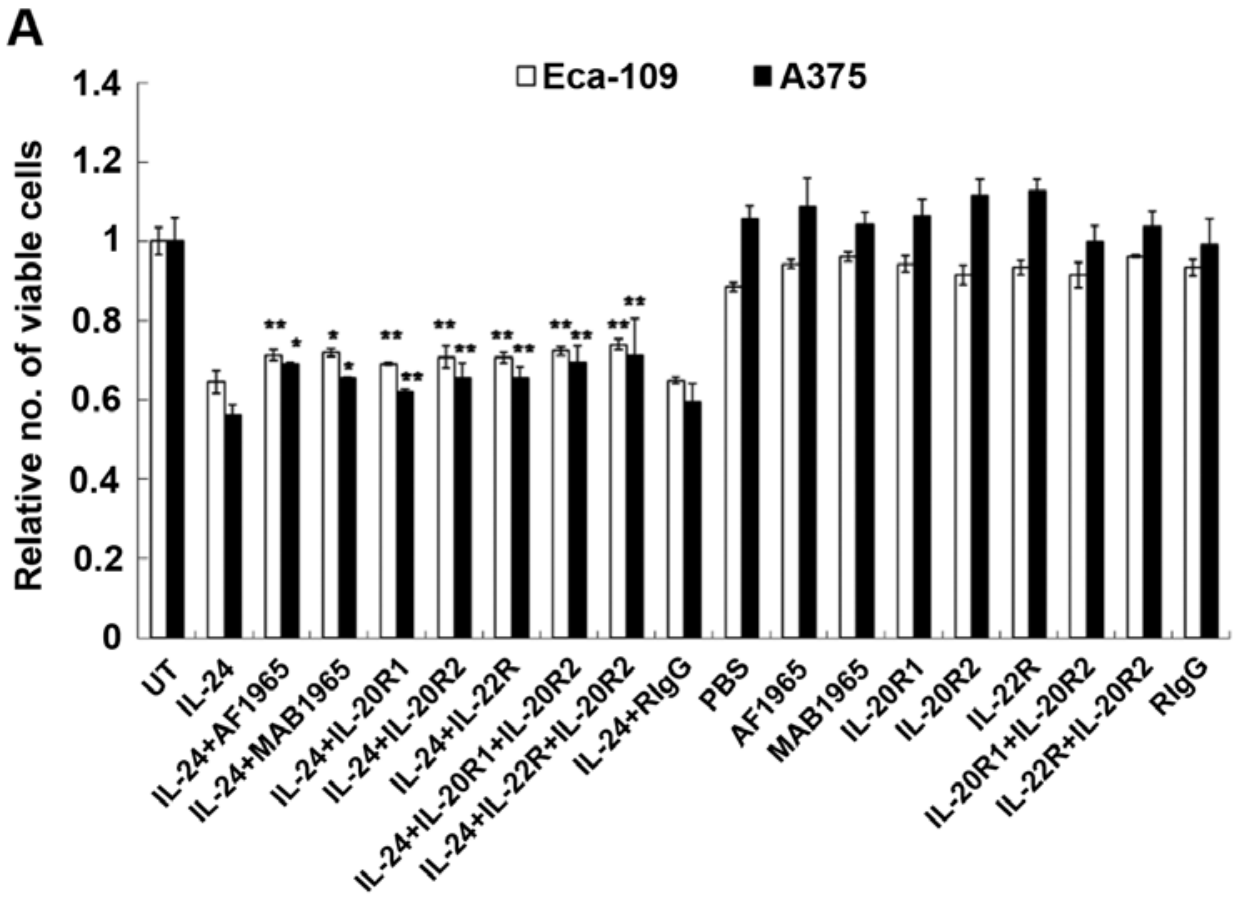

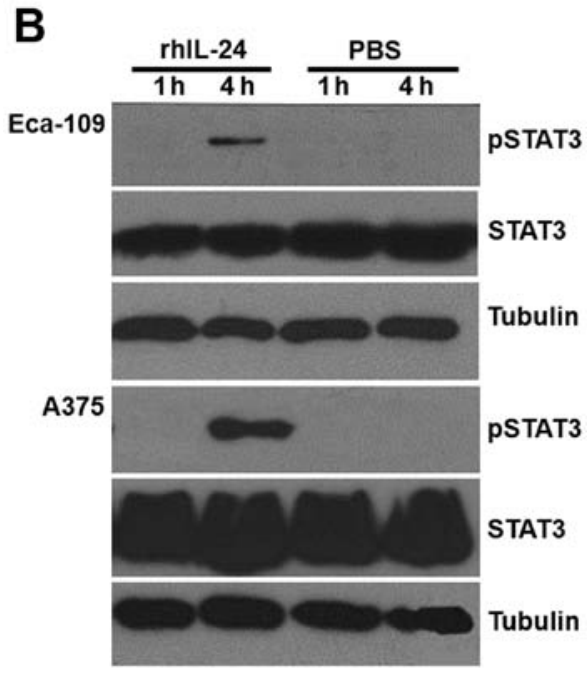

to induce tumors in nude mice. After 5-7 days following s.c. injection of $5 \times 10^{6}$ Eca-109 cells into nude mice, the tumors reached $50-100 \mathrm{~mm}^{3}$, which was more rapid than the animals that received $1 \times 10^{6}$ or $2 \times 10^{6}$ cells (data not shown). At the same time, we verified whether parental FCHO cells and gene engineered $\mathrm{FCHO} / \mathrm{IL}-24$ cells could induce tumors in nude mice. Injection of $1 \times 10^{6}$ or $2 \times 10^{6}$ of FCHO or FCHO/IL-24 cells alone for 30 days did not induce tumors in the nude mice (data not shown). Then, the animals in the experimental group were injected s.c. with a total of $7 \times 10^{6}$ cells containing a mixture of Eca-109 and FCHO/IL-24 cells (2.5:1 ratio). For animals in the control group, Eca-109 and FCHO cells were mixed and injected s.c. as described above. After 30 days, the growth of tumors was significantly suppressed by $67 \%$ (mean value) in the animals of the experimental group compared with the control group (Fig. 4A; p<0.05). There was no significant differences in the tumor cell mitotic index or tissue infiltration and tumor cell proliferative index between the two group as determined
Figure 3. rhIL-24 protein kills Eca-109 cells and activates STAT3 which may be related with the IL-20 receptor pathway. (A) The suppressive effects of rhIL-24 protein on Eca-109 and A375 cells were neutralized by anti-IL-24 or anti-IL-20R antibodies. Eca-109 and A375 cells were treated with $20 \mathrm{ng} /$ $\mathrm{ml}$ rhIL-24 plus $200 \mathrm{ng} / \mathrm{ml}$ of the various antibodies (anti-IL-24 antibody, AF1965 and MAB1965; anti-IL-20 receptor antibody, IL-20R1, IL-20R2 or IL-22R1) as indicated for 4 days. Cell viability was evaluated using a standard MTT assay. The numbers represent the ratio of the specific treatments indicated vs. control cells; the columns indicate the average of three independent experiments $(n=3)\left({ }^{* *} p<0.01\right.$ and $\left.{ }^{*} p<0.05\right)$. (B) STAT3 was activated by purified srhIL-24 protein. A375 and Eca-109 cells were treated with $20 \mathrm{ng} / \mathrm{ml}$ srhIL-24 for 1 and $4 \mathrm{~h}$, respectively, and pSTAT3 and STAT3 were analyzed using anti-pSTAT3 and anti-STAT3 antibodies by western blotting. Cells treated with PBS served as a control, and tubulin as the internal standard.

by H\&E and PCNA staining, respectively (Fig. 4B and C). However, less vascularization as determined by CD34 staining was detected in tumor tissues of the experimental group than that noted in the control group (Fig. 4D and E; $\mathrm{p}<0.01$ ). The reduction in CD34 staining indicated that secreted rhIL-24 inhibited angiogenesis in the tumor tissues of nude mice. Compared with tumor tissues of the control group, a higher number of TUNEL-positive stained cells were observed in tumor cells of the experimental group (Fig. 4F and G; p<0.01). Immunohistochemical analysis with an anti-IL-24 antibody in the tumor sections of the experimental group demonstrated IL-24 protein expression (Fig. 4H). In contrast, IL-24 was not detected in the tumor sections of the control group. Finally, we ascertained whether the growth of formed tumor xenografts could be inhibited by rhIL-24 protein secreted by FCHO/ IL-24 cells. When the tumors reached $50-100 \mathrm{~mm}^{3}$ following s.c. injection of Eca-109 cells $\left(5 \times 10^{6}\right)$ in the lower right flank of nude mice, $2 \times 10^{6} \mathrm{FCHO} / \mathrm{IL}-24$ cells resuspended in Matrigel 
A
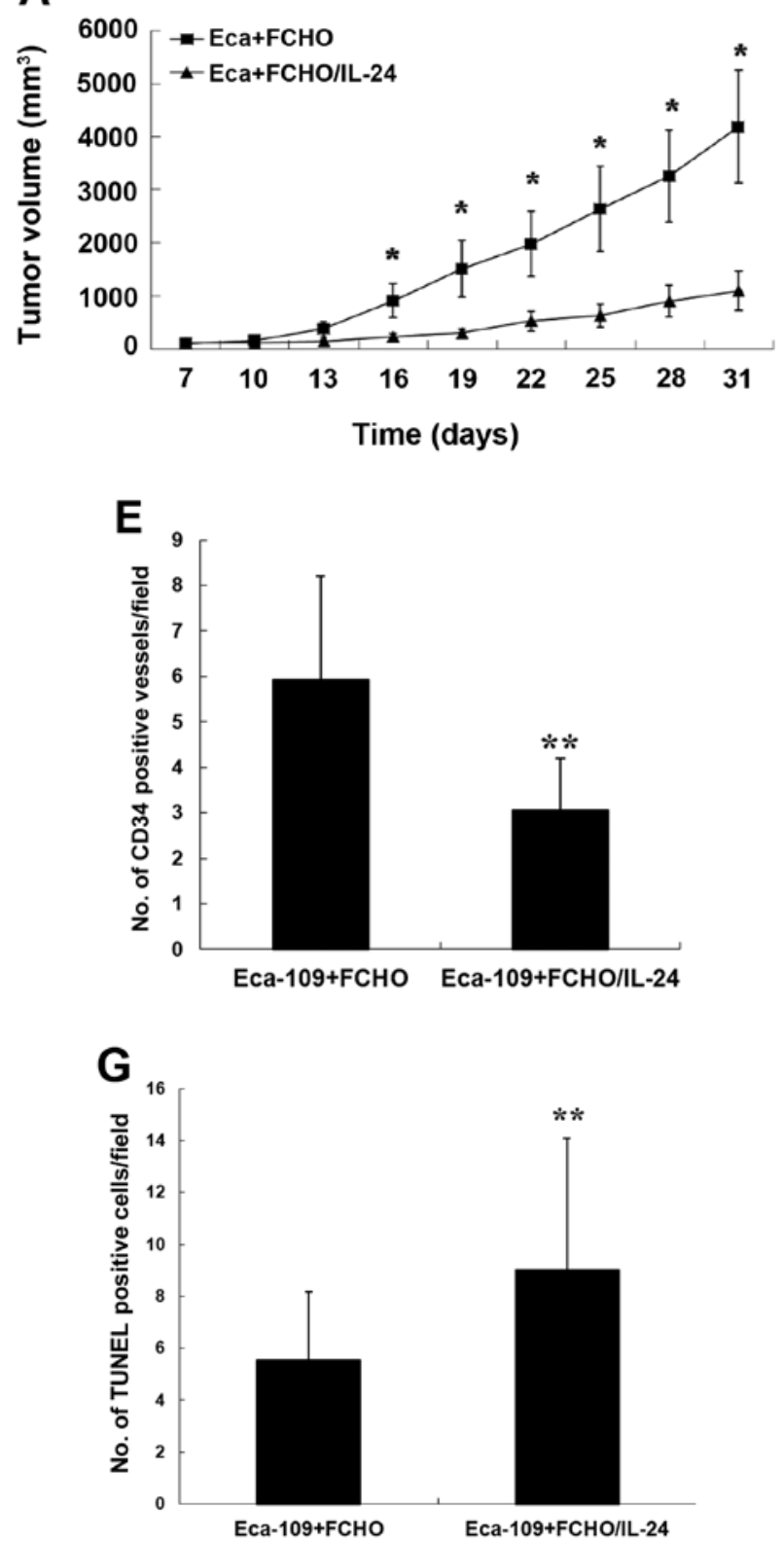

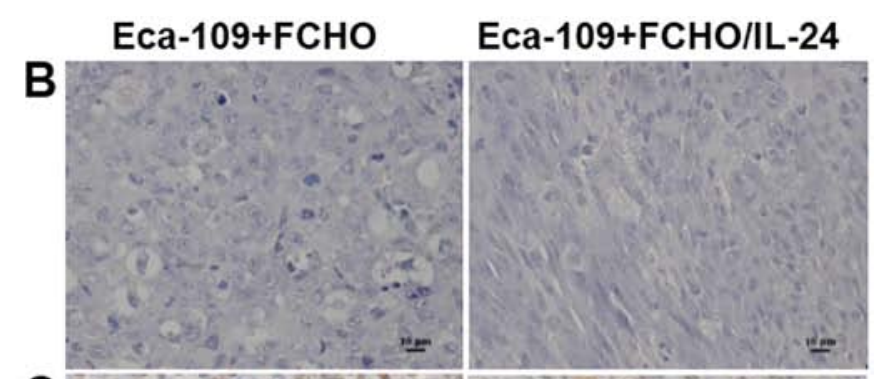

C

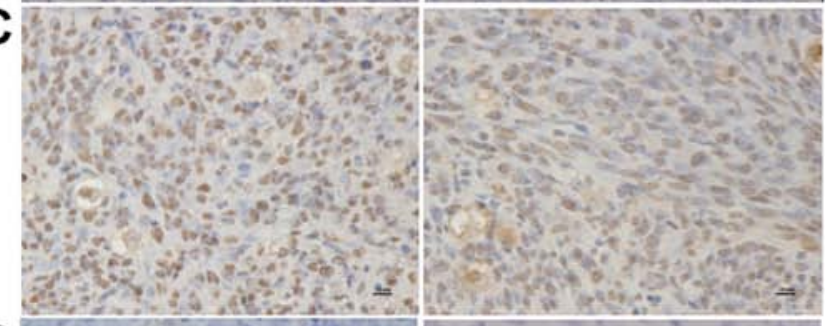

D

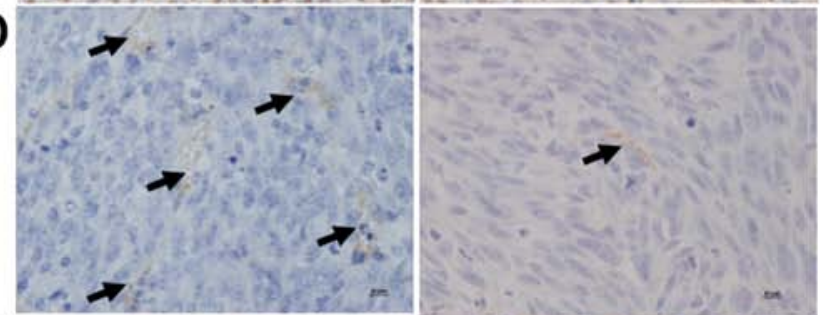

$\mathbf{F}$

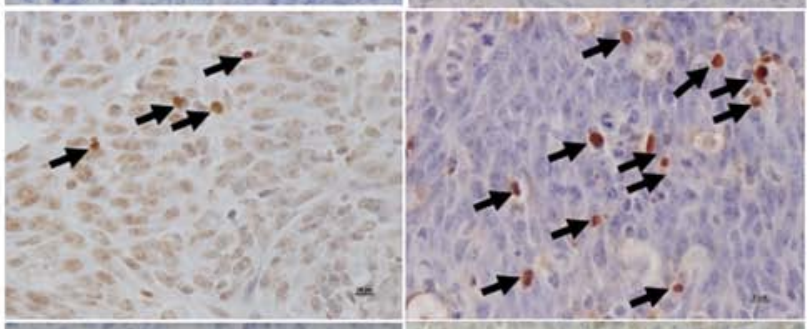

H

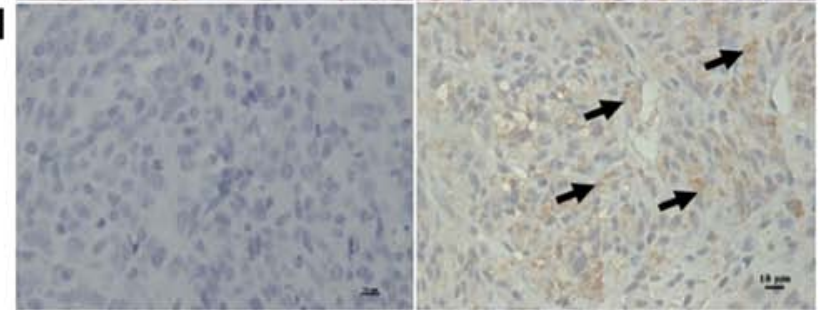

Figure 4. srhIL-24 inhibits the tumorigenicity of Eca-109 cells in nude mice. (A) The volume of tumors following s.c. injection of a mixture of Eca-109 tumor cells with FCHO cells $(\mathbf{\square})$ or FCHO/IL-24 cells $(\mathbf{\Lambda})$ (2.5:1) in nude mice. Tumor growth was significantly inhibited in animals of the experimental group receiving a mixture of Eca-109 and FCHO/IL-24 cells compared with animals of the control group receiving a mixture of Eca-109 and FCHO cells $(\mathrm{p}<0.05)$. The bars represent the standard error. (B) There was no differences in tumor cell mitotic index and tissue infiltration of tissue sections between the experimental group and control group as determined by staining with H\&E. (C) Immunohistochemical staining for PCNA showed no differences in tumor cell proliferative index. (D) Downregulation of CD34 expression in tumor sections of the experimental group; arrows denote the areas staining positive for CD34. (E) The number of CD34-positive vessels was significantly less in the tumor sections of the experimental group (**p<0.01) than that in the tumor sections of the control group/field. (F) Tumor cells undergoing apoptosis are indicated by brown staining using the TUNEL method. Arrows show apoptotic cells. (G) The number of TUNEL-positive cells were higher in the tumor sections of the experimental group compared with that in the control group/field ( $\left.{ }^{* *} \mathrm{p}<0.01\right)$. (H) IL-24 protein expression was observed in the cytoplasm of the tumor cells of the experimental group, but not in the tumor sections of the control group. Arrows denote tumor cells expressing IL-24 protein.

were injected s.c. in the upper right flank of the experimental group animals. The animals of the control group received the same number of $\mathrm{FCHO}$ cells resuspended in Matrigel at the same site. The day of implantation of FCHO or FCHO/ IL-24 cells was recorded as the first day and tumor volume was measured as described above. Compared with the tumors of the control group, the growth of Eca-109 tumor xenografts in the experimental group was significantly inhibited by $29 \%$ (mean value) (Fig. 5A; p<0.05) after 30 days. Similar to the findings described above, there was no significant difference in staining by the H\&E or anti-Ki-67 antibody in the tumor tissues between the two groups (Fig. 5B and C). In addition, the tumor tissues of the experimental group showed significantly less CD34-positive staining (Fig. 5D and E; $\mathrm{p}<0.01$ ) and more TUNEL-positive staining (Fig. 5F and G; $\mathrm{p}<0.01)$ than that of the control group. The IL-24 protein was expressed in the tumor sections of the experimental group, but not in the tumor sections of the control group (Fig. 5H). These 
A
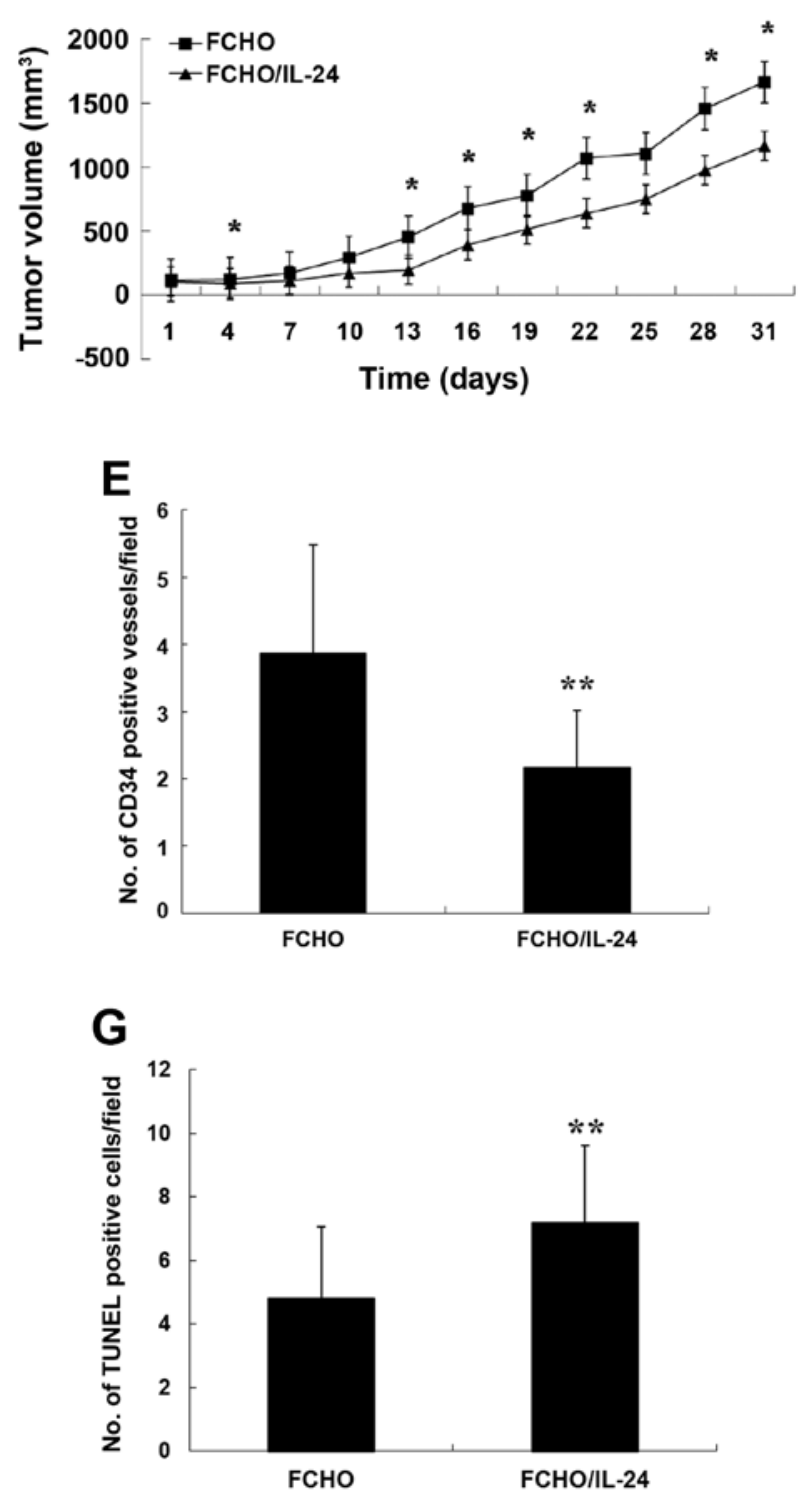
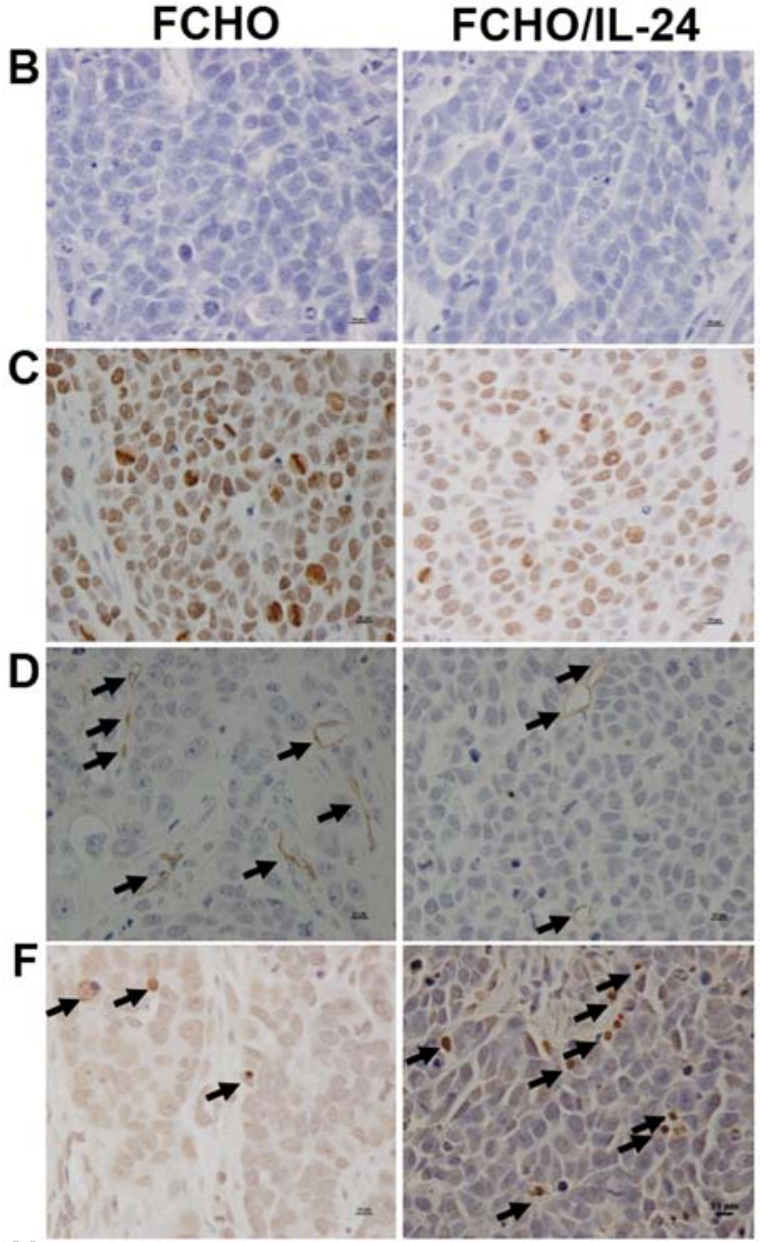

H

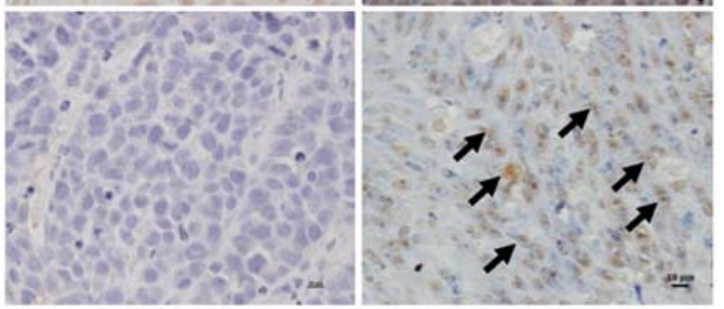

Figure 5. The growth of Eca-109 tumor xenografts is inhibited by srhIL-24. (A) Eca-109 cells $\left(5 \times 10^{6}\right)$ were injected s.c. in the lower right flank to induce tumors $\left(50-100 \mathrm{~mm}^{3}\right)$. The growth of tumors was significantly inhibited in animals of the experimental group receiving FCHO/IL-24 cells resuspended in Matrigel $(\boldsymbol{\Lambda})$ into the upper right flank, compared with animals of the control group receiving FCHO cells resuspended in Matrigel $(\boldsymbol{\square})\left({ }^{*} \mathrm{p}<0.05\right)$. The bars represent the standard error. (B) There was no differences in tumor cell mitotic index and tissue infiltration of tissue sections between the experimentsl and control groups stained with H\&E. (C) Immunohistochemical staining for Ki-67 showed no differences in tumor cell proliferative index. (D) Downregulation of CD34 expression in tumor sections of the experimental group; arrows denoted areas of positive staining for CD34. (E) The number of CD34-positive vessels was significantly less in tumor sections of the experimental group $\left({ }^{* *} \mathrm{p}<0.01\right)$ than in tumor sections of the control group/field. (F) Tumor cells undergoing apoptosis are indicated by brown staining using the TUNEL method. Arrows show apoptotic cells. (G) The number of cells in the tumor sections of the experimental groups stained positive for TUNEL were increased compared with the number in the tumor sections of the control group/field $\left({ }^{* *} \mathrm{p}<0.01\right)$. (H) IL-24 protein expression was observed in the cytoplasm of the tumor cells of the experimental group, but not in the tumor sections of the control group. Arrows denote tumor cells expressing IL-24 protein.

results demonstrated that srhIL-24 inhibited tumor growth by reducing angiogenesis and inducing apoptosis in vivo.

\section{Discussion}

Since 1995, numerous publications have shown that IL-24 selectively kills a large variety of cancer cells in vivo and in vitro and leaves healthy cells unharmed. Due to the lack of post-translational modification, particularly glycosylation, rhIL-24 protein expressed from E. coli plays a role at very high concentrations $(\mu \mathrm{g} / \mathrm{ml})(25)$, or has no activity (26) on tumor cells. In contrast, rhIL-24 from mammalian cells plays an antitumor role at a substantially lower concentration $(\mathrm{ng} / \mathrm{ml})(17,23)$, but the expression level is lower. At present, there are several reported methods to prepare rhIL-24 from mammalian cells, such as overexpression of plasmid pCEP4-IL-24 in HEK293 cells $(7,16,27)$ and infection of immortal normal human $(14,19)$ or tumor cells (13) with Ad-IL-24. In the present study, we aimed to improve the expression level of srhIL-24 protein using a site-specific 
integrated cell line. Compared with three random-integrated cell lines, HEK293/pSecTag2A-IL-24, HEK293/ pcDNA3.1myc/His-IL-24 and HEK293/pCEP4-IL-24, the expression level of srhIL-24 from the site-specific $\mathrm{FCHO} /$ IL-24 cells was the highest, with markedly differences and reached 7.4 and $8.0 \mathrm{ng} / \mathrm{ml}$ on day 3 and 4 , respectively. This may be the first study to compare the expression level of srhIL-24 from different gene engineered cell lines. Caudell et al transfected plasmid pCEP4-IL-24 into HEK293 cells and the concentration of rhIL-24 in the crude supernatant of an aliquot of $10^{6}$ cells in $24 \mathrm{~h}$ was $30-50 \mathrm{ng} / \mathrm{ml}$ (7). Since there was no detailed information concerning the cell culture, such as the positive ratio of cells overexpressing rhIL-24, the culture medium volume, cell density or plate size, we were unable to compare our results with theirs. They obtained purified srhIL-24 protein with a concentration of $300 \mathrm{ng} / \mathrm{ml}$ as determined by ELISA (7) and ours was $500 \mathrm{ng} / \mathrm{ml}$. Then, we analyzed the biological function of srhIL-24 in vitro on ESCC Eca-109 cells. srhIL-24 inhibited the growth and colony formation $(1-50 \mathrm{ng} / \mathrm{ml})$ and induced apoptosis $(1-40 \mathrm{ng} / \mathrm{ml})$ in a dose-dependent manner. The concentration of srhIL-24 was similar to other studies $(13,14,23,27)$. In contrast to Ad-IL-24, rhIL-24 protein did not have any biological effect in vitro on tumor cells lacking expression of the IL-20R complexes, such as human lung cancer A549 cells $(14,27)$, and we obtained similar results. At present, the mechanism involved in srhIL-24 protein from mammalian cells in regards to the preferential killing activity against cancer cells is in a receptor-dependent fashion $(15,23)$. srhIL-24 binds to the IL-20R complexes consisted of two sets of heterodimeric chains, IL-20R1/ IL-20R2 or IL-22R1/IL-20R2 (28). Our previous results (21) showed that Eca-109, A375 and HEL cells expressed three types of subunits and A549 cells just positively stained for IL-20R2. In the present study, the results using anti-IL-24 or anti-IL-20R neutralizing antibodies $(200 \mathrm{ng} / \mathrm{ml})$ indicated that srhIL-24 killed Eca-109 and A375 cells in a receptormediated manner, and two types of IL-20R complex were involved. Upon ligand binding, both receptors induced the phosphorylation of STAT3 and its trans-location to the nucleus, demonstrating that the JAK-STAT signaling pathway has indeed been activated (28). The concentration of rhIL-24 was usually $10-50 \mathrm{ng} / \mathrm{ml}$, and the target cells were treated from $30 \mathrm{~min}$ to $4 \mathrm{~h}(12,23)$. From our results, the STAT3 in Eca-109 cells or A375 cells was apparently phosphorylated after cells were treated with srhIL-24 $(20 \mathrm{ng} / \mathrm{ml})$ for $4 \mathrm{~h}$. Apart from the phosphorylation of STAT3, srhIL-24 also functions through different pathways, such as increasing IL-24 mRNA stability and endogenous IL-24 protein expression in normal and cancer cells (14), inducing a bystander antitumor effect through an ER stress mechanism and increasing reactive oxygen species (ROS) production similar to Ad-IL-24 infection (14), upregulating the tumor-suppressor proteins p53 $(13,17)$, p27 ${ }^{\mathrm{Kip} 1}(17)$ and cell cycle regulator p21 $(13,23)$.

Numerous studies have identified the antitumor activity of IL-24 in vivo by direct injection of Ad-IL-24 (29) into tumorbearing nude mice, and several using adeno-associated virus IL-24 (30) or plasmid (31). With regard to rhIL-24 protein, there were no studies that directly injected the recombinant protein, no matter whether the rhIL-24 was expressed in $E$. coli or mammalian cells. The possible reasons are lower activity and lower expression level, respectively. In this experiment, the ultimate collection of rhIL-24 protein was not sufficient for in vivo investigations; therefore, we injected s.c. FCHO/IL-24 cells to identify the antitumor function of srhIL-24 in vivo according to Ramesh et al (16). They mixed $5 \times 10^{5}$ tumor cells (A549) with an equal number $\left(5 \times 10^{5}\right)$ of HEK-293/IL-24 cells, and every animal received $10^{6}$ cells (ratio, $1: 1$ ). In the present study, the ratio of tumor (Eca-109) and FCHO/IL-24 or FCHO cells was $2.5: 1$, and every animal received $7 \times 10^{6}$ cells. Following injection of a mixture of FCHO/IL-24 and Eca-109 cells, and also injection of FCHO/IL-24 cells resuspended in Matrigel into tumor-bearing nude mice, tumor growth was significantly inhibited in the experimental animals that received $\mathrm{FCHO} /$ IL-24 cells compared with the control animals that received FCHO cells after 30 days. However, when FCHO/IL-24 and Eca-109 cells were mixed and injected at the same time, the effect of srhIL-24 was more evident. The reason may be that FCHO-IL-24 cells induced the apoptosis of Eca-109 cells as soon as the two types of cells were mixed. The mechanism by which sIL-24 inhibited tumor growth in vivo possibly involves at least three functions: tumoricidal effects, anti-angiogenic activity and modulation of immune responses.

In summary, we demonstrated that rhIL-24 was secreted at a higher level from the site-specific integrated FCHO/IL-24 cells than three random-integrated cell lines. The purified srhIL-24 inhibited proliferation and induced apoptosis of ESCC Eca-109 cells in vitro and in vivo and activated STAT3, which may be mediated by the receptor pathway. Further preliminary research should be performed. Studies should be carried out to treat tumors using rhIL-24 and should aim to improve the expression level, the suspension culture of engineeried cells in medium-free fetal bovine serum, to improve the half-life of purified rhIL-24 protein by polyethyleneglycol modification, and to identify more effective delivery systems. These insights should pave the way for enhanced translational applications of rhIL-24 for the therapy of human cancers.

\section{Acknowledgements}

The present study was supported by the Beijing Natural Science Foundation (grant no. 7142117) to Q.F. Ma and the National High Technology Research and Development Program of China (863 Program, grant no. 2014AA021605) to Z.L. Wang.

\section{References}

1. Jemal A, Bray F, Center MM, Ferlay J, Ward E and Forman D: Global cancer statistics. CA Cancer J Clin 61: 69-90, 2011.

2. Wang JB, Fan JH, Liang H, Li J, Xiao HJ, Wei WQ, Dawsey SM, Qiao YL and Boffetta P: Attributable causes of esophageal cancer incidence and mortality in China. PLoS One 7: e42281, 2012.

3. Burrows WM: Gastrointestinal function and related problems following esophagectomy. Semin Thorac Cardiovasc Surg 16: $142-151,2004$.

4. Xu YW, Peng YH, Chen B, Wu ZY, Wu JY, Shen JH, Zheng CP, Wang SH, Guo HP, Li EM, et al: Autoantibodies as potential biomarkers for the early detection of esophageal squamous cell carcinoma. Am J Gastroenterol 109: 36-45, 2014

5. Jiang H, Lin JJ, Su ZZ, Goldstein NI, and Fisher PB: Subtraction hybridization identifies a novel melanoma differentiation associated gene, mda-7, modulated during human melanoma differentiation, growth and progression. Oncogene 11: 2477-2486, 1995. 
6. Gupta P, Su ZZ, Lebedeva IV, Sarkar D, Sauane M, Emdad L, Bachelor MA, Grant S, Curiel DT, Dent P, et al: $m d a-7 / \mathrm{IL}-24$ : Multifunctional cancer-specific apoptosis-inducing cytokine. Pharmacol Ther 111: 596-628, 2006.

7. Caudell EG, Mumm JB, Poindexter N, Ekmekcioglu S, Mhashilkar AM, Yang XH, Retter MW, Hill P, Chada S and Grimm EA: The protein product of the tumor suppressor gene, melanoma differentiation-associated gene 7, exhibits immunostimulatory activity and is designated IL-24. J Immunol 168 6041-6046, 2002.

8. Fisher PB: Is $m d a-7 / I L-24$ a 'magic bullet' for cancer? Cancer Res 65: 10128-10138, 2005.

9. Su ZZ, Lebedeva IV, Sarkar D, Gopalkrishnan RV, Sauane M, Sigmon C, Yacoub A, Valerie K, Dent P and Fisher PB: Melanoma differentiation associated gene-7, $m d a-7 /$ IL-24, selectively induces growth suppression, apoptosis and radiosensitization in malignant gliomas in a $p 53$-independent manner. Oncogene 22: 1164-1180, 2003

10. Wang J, Fan X, Bao L and Du L: Construction of eukaryotic expression vector of EGFRi-IL-24 recombinant gene. Sheng Wu Yi Xue Gong Cheng Xue Za Zhi 27: 395-399, 2010 (In Chinese).

11. Sieger KA, Mhashilkar AM, Stewart A, Sutton RB, Strube RW Chen SY, Pataer A, Swisher SG, Grimm EA, Ramesh R, et al: The tumor suppressor activity of MDA-7/IL-24 is mediated by intracellular protein expression in NSCLC cells. Mol Ther 9: 355-367, 2004

12. Ekmekcioglu S, Ellerhorst JA, Mumm JB, Zheng M, Broemeling L, Prieto VG, Stewart AL, Mhashilkar AM, Chada S and Grimm EA: Negative association of melanoma differentiation-associated gene $(m d a-7)$ and inducible nitric oxide synthase (iNOS) in human melanoma: MDA-7 regulates iNOS expression in melanoma cells. Mol Cancer Ther 2: 9-17, 2003.

13. Zheng M, Bocangel D, Ramesh R, Ekmekcioglu S, Poindexter N, Grimm EA and Chada S: Interleukin-24 overcomes temozolomide resistance and enhances cell death by down-regulation of $O^{6}$-methylguanine-DNA methyltransferase in human melanoma cells. Mol Cancer Ther 7: 3842-3851, 2008.

14. Sauane M, Su ZZ, Gupta P, Lebedeva IV, Dent P, Sarkar D and Fisher PB: Autocrine regulation of $m d a-7 / \mathrm{IL}-24$ mediates cancerspecific apoptosis. Proc Natl Acad Sci USA 105: 9763-9768, 2008

15. Chada S, Bocangel D, Ramesh R, Grimm EA, Mumm JB, Mhashilkar AM and Zheng M: $m d a-7 / I L 24$ kills pancreatic cancer cells by inhibition of the Wnt/PI3K signaling pathways: Identification of IL-20 receptor-mediated bystander activity against pancreatic cancer. Mol Ther 11: 724-733, 2005.

16. Ramesh R, Mhashilkar AM, Tanaka F, Saito Y, Branch CD, Sieger K, Mumm JB, Stewart AL, Boquoi A, Dumoutier L, et al: Melanoma differentiation-associated gene 7/interleukin (IL)-24 is a novel ligand that regulates angiogenesis via the IL-22 receptor. Cancer Res 63: 5105-5113, 2003.

17. Zheng M, Bocangel D, Doneske B, Mhashilkar A, Ramesh R, Hunt KK, Ekmekcioglu S, Sutton RB, Poindexter N, Grimm EA, et al: Human interleukin 24 (MDA-7/IL-24) protein kills breast cancer cells via the IL-20 receptor and is antagonized by IL-10. Cancer Immunol Immunother 56: 205-215, 2007.

18. Lebedeva IV, Su ZZ, Sarkar D and Fisher PB: Restoring apoptosis as a strategy for cancer gene therapy: Focus on p53 and mda-7. Semin Cancer Biol 13: 169-178, 2003
19. Su Z, Emdad L, Sauane M, Lebedeva IV, Sarkar D, Gupta P, James CD, Randolph A, Valerie K, Walter MR, et al: Unique aspects of $m d a-7 / \mathrm{IL}-24$ antitumor bystander activity: Establishing a role for secretion of MDA-7/IL-24 protein by normal cells. Oncogene 24: 7552-7566, 2005.

20. Ma G, Kawamura K, Shan Y, Okamoto S, Li Q, Namba M, Shingyoji M, Tada Y, Tatsumi K, Hiroshima K, et al: Combination of adenoviruses expressing melanoma differentiation-associated gene-7 and chemotherapeutic agents produces enhanced cytotoxicity on esophageal carcinoma. Cancer Gene Ther 21: 31-37, 2014.

21. Ma Q, Deng X, Jin B, Zhang Y, Luo D, Song H, Wang P, Zhang C, Li X, Shi Y, et al: A novel human interleukin-24 peptide created by computer-guided design contributes to suppression of proliferation in esophageal squamous cell carcinoma Eca-109 cells. Oncol Rep 33: 193-200, 2015.

22. Yang J, Zhang W, Liu K, Jing S, Guo G, Luo P and Zou Q: Expression, purification, and characterization of recombinant human interleukin 24 in Escherichia coli. Protein Expr Purif 53: 339-345, 2007.

23. Chada S, Mhashilkar AM, Ramesh R, Mumm JB, Sutton RB, Bocangel D, Zheng M, Grimm EA and Ekmekcioglu S: Bystander activity of Ad-mda7: Human MDA-7 protein kills melanoma cells via an IL-20 receptor-dependent but STAT3-independent mechanism. Mol Ther 10: 1085-1095, 2004.

24. Aggarwal S, Takada Y, Mhashilkar AM, Sieger K, Chada S and Aggarwal BB: Melanoma differentiation-associated gene-7/ IL-24 gene enhances NF-kappa B activation and suppresses apoptosis induced by TNF. J Immunol 173: 4368-4376, 2004

25. Yacoub A, Mitchell C, Hong Y, Gopalkrishnan RV, Su ZZ, Gupta P, Sauane M, Lebedeva IV, Curiel DT, Mahasreshti PJ, et al: MDA-7 regulates cell growth and radiosensitivity in vitro of primary (non-established) human glioma cells. Cancer Biol Ther 3: 739-751, 2004

26. Kreis S, Philippidou D, Margue C, Rolvering C, Haan C, Dumoutier L, Renauld JC and Behrmann I: Recombinant interleukin-24 lacks apoptosis-inducing properties in melanoma cells. PLoS One 2: e1300, 2007.

27. Mumm JB, Ekmekcioglu S, Poindexter NJ, Chada S and Grimm EA: Soluble human MDA-7/IL-24: Characterization of the molecular form(s) inhibiting tumor growth and stimulating monocytes. J Interferon Cytokine Res 26: 877-886, 2006.

28. Dash R, Bhutia SK, Azab B, Su ZZ, Quinn BA, Kegelmen TP, Das SK, Kim K, Lee SG, Park MA, et al: $m d a-7 / I L-24$ : A unique member of the IL-10 gene family promoting cancer-targeted toxicity. Cytokine Growth Factor Rev 21: 381-391, 2010.

29. Saeki T, Mhashilkar A, Swanson X, Zou-Yang XH, Sieger K, Kawabe S, Branch CD, Zumstein L, Meyn RE, Roth JA, et al: Inhibition of human lung cancer growth following adenovirusmediated $m d a-7$ gene expression in vivo. Oncogene 21: 4558-4566, 2002.

30. Tamai H, Miyake K, Yamaguchi H, Takatori M, Dan K, Inokuchi K and Shimada T: AAV8 vector expressing IL24 efficiently suppresses tumor growth mediated by specific mechanisms in $M L L / A F 4$-positive ALL model mice. Blood 119: 64-71, 2012.

31. Gu J, Chen X, Xin H, Fang X and Sha X: Serum-resistant complex nanoparticles functionalized with imidazole-rich polypeptide for gene delivery to pulmonary metastatic melanoma. Int J Pharm 461: 559-569, 2014. 